\title{
Soil physical attributes and productivity of sugarcane under different cropping systems in the savannah goiano
}

\author{
Regina Maria Quintão Lana ${ }^{1}$, Luis Augusto da Silva Domingues ${ }^{2}$, José Luiz Rodrigues Torres ${ }^{3^{*}}$, Jose \\ Geraldo Mageste ${ }^{4}$, Emmerson Rodrigues de Moraes ${ }^{5}$
}

\author{
${ }^{1}$ Soils and Nutrition of Plants, Institute of Agricultural Sciences at the Federal University of Uberlândia, MG, \\ Brazil \\ ${ }^{2}$ Phytotechny, Federal Institute of Mining Triangle - Uberlandia, MG, Brazil \\ ${ }^{3}$ Crop Production, Federal Institute of Mining Triangle - Uberaba, MG, Brazil \\ ${ }^{4}$ Forestry Science, Institute of Agricultural Sciences at the Federal University of Uberlandia, MG, Brazil \\ ${ }^{5}$ Graduate Program in Agronomy, Institute of Agricultural Sciences at the Federal University of Uberlandia, \\ MG, Brazil
}

*Corresponding author: jlrtorres@iftm.edu.br

\begin{abstract}
The cultivation systems of sugarcane can cause changes to the soil's physical properties and root development, which in turn, can affect the productivity of the crop. The main objective of this study was to evaluate different soil management systems and their influence on the physical attributes of soil, plant root system development and the productivity of plant cane in re-established area. The experimental design was randomized blocks in $6 \times 3$ factorial scheme with 4 repetitions. The soil treatments were: $\mathrm{T}_{1}=$ Desiccation + moldboard plowing + light harrow (DPH); $\mathrm{T}_{2}=$ Subsoiler + light harrow $(\mathrm{SH}) ; \mathrm{T}_{3}=$ Desiccation + no-tillage $(\mathrm{DNT})$; $\mathrm{T}_{4}=$ Desiccation + subsoiler (DS); $\mathrm{T}_{5}=$ stubble thrasher + subsoiler $(\mathrm{StS})$ and $\mathrm{T}_{6}=$ stubble thrasher + mid harrow + moldboard plow + light harrow (StHPH), each evaluated at three depths $(0.0-0.20 ; 0.20-0.40$ and $0.40-0.60 \mathrm{~m})$. The effects of these treatments were evaluated by analyzing physical properties of soil, root development of the plants and productivity of the crop. All evaluated tillage systems improved penetration resistance, but only to the depth of $0.20 \mathrm{~m}$. The best rates of root development occurred with the T1 treatment. Root development was significantly lower with higher penetration resistance values in all evaluated systems. Sugarcane productivity was significantly higher in systems with greater soil disturbance.
\end{abstract}

Keywords: Saccharum officinarum, root system, Cerrado, no-tillage.

Abbreviations: Hs_ Hectares; PR _ Penetration Resistance; SD _ Soil Density; GM _ Gravimetric moisture; Ma _ Macroporosity; Mi _ Microporosity; TP _ Total Porosity; DPH _ Desiccation + moldboard plowing + light harrow; SH _ Subsoiler + light harrow; DNT_ Desiccation + no-tillage; DS - Desiccation + subsoiler; StS _ Stubble thrasher + subsoiler; StHPH _ Stubble thrasher + mid harrow + moldboard plow + light harrow.

\section{Introduction}

Brazil is the largest producer of sugarcane destined for sugar and ethanol, occupying an area of about 9.0 million hectares (Hs) with prospects for expansion in the coming years. In the 2014/15 season the State of Goiás remained as the second largest national producer, cultivating an area of $854.200 \mathrm{Hs}$, equivalent to $9.5 \%$ of national production (Conab, 2015).

Sugarcane cultivation systems involve a large number of operations with heavy farm machinery as tilling, mechanized harvesting and in-field transport, which raise the possibility of compaction and increased soil density (Cavalieri et al., 2011). Repetitive in-field traffic during the crop cycle, which occurs under different soil moisture conditions (Oliveira Filho et al., 2015), hampers normal root development and crop productivity. This set of tilling operations reduces soil macroporosity, aggregate size, water infiltration, and increases soil density and resistance to root penetration (Vasconcelos et al., 2010), thus reducing the performance of the crop. Some soil physical attributes are frequently used as indicators of change in soil quality including: soil density, compaction, porosity, water retention capacity and aggregate stability (Torres et al., 2015). The development of cane root system directly influences the productivity. The system is responsible for the uptake and transport of water and nutrients from the soil solution and the support of the plant. Therefore, the attributes physical, chemical and biological has a direct impact on the distribution of roots. However, the determining factor is not the amount of these variations, but their distribution throughout the soil profile (Vasconcelos et al., 2008). Knowing the variability of the physical attributes of an Oxisol under sugarcane, Pellin et al. (2015) observed that increased volumetric humidity at $0.00-0.20 \mathrm{~m}$ depth provided increased yield by approximately $24 \%$ per hectare due to higher amount of water in the soil.

Some studies have proven that products based on humic and fulvic substances increase the absorption of water and nutrients by sugarcane plants, what improves root development and consequently agronomic performance of the plants (Souza et al., 2014; Oliveira Filho et al. 2015). 
In recent years the soil tillage, planting and cultivation systems of agricultural crops have evolved. In some areas the minimum tillage and no-tillage have been adopted to replace conventional systems (Tavares et al., 2015; Campos et al., 2015). In addition to these systems, other possibilities need to be studied. But to date few experiments have been conducted. This study evaluated the use of different tillage systems and their influence on physical attributes of soil, root development and productivity of plant cane after replanting.

\section{Results and Discussion}

\section{Physical attributes}

Penetration resistance $(P R)$, soil density $(S d)$ and gravimetric moisture (GM)

Analyzing soil physical attributes, we observed that there were significant interactions between treatments and the depths (Table 1). The soil penetration resistance (PR) values were lower for the depth up to $0.20 \mathrm{~m}$ when compared to other depths (0.20-0.40 and 0.40-0.60 m) without significant differences among tillage systems. This behavior suggests that the use of the furrower at planting in all treatments, reaching a depth of $0.40 \mathrm{~m}$, decreased soil compaction in the surface layer. It can also be noted that the action of agricultural implements used to decrease PR in the surface layer did not reach the same goal of soil decompression at depths below $0.20 \mathrm{~m}$, as in all treatments PR was above 6,0 MPa.

In a study of soil physical properties and productivity of maize, Sene et al. (1985) observed that values between 6.0 to 7.0 MPa are regarded as critical to the full growth of the roots of plants in sandy soils and $2.5 \mathrm{MPa}$ for clay. In a review, Torres and Scott (1999) point out that, in general, the maximum root development in crops occurs when the resistance of the soil is around 0.5 to $1.0 \mathrm{MPa}$. Above these values, an increased resistance causes a reduction in the growth of roots which, depending on the species, can stop the growth when values from 2.5 to $6.5 \mathrm{Mpa}$ are reached. It is though understood that the resistance of around $3.5 \mathrm{MPa}$ is a low indicative of compression and $6.5 \mathrm{MPa}$ is high.

In the same area and in a similar study, Azevedo (2008) evaluated three types of soil preparation treatments under sugarcane for two consecutive years, and found that PR values ranged from 1.5 to $9.6 \mathrm{MPa}$, which is higher than the values obtained in our study. Carvalho et al. (2014) also evaluated the relation between soil physical properties and the productivity of sugarcane using different tillage systems during replanting. They observed that tillage operations with: subsoiler in the row + disc harrow, moldboard plow + disk harrow or subsoiler in total area + disk harrow provided greater crop yield.

The soil density (SD) and gravimetric moisture (GM) values did not vary significantly among depths and treatments, suggesting that these parameters did not increase PR in the deeper layers. Torres and Scott (1999) pointed out that the negative effect of PR on root development is associated with soil moisture because drier soils demonstrate higher PR and BD and lower root growth.

\section{Macroporosity (Ma), microporosity (Mi) and total porosity} (TP)

In the surface layer $(0.0$ to $0.20 \mathrm{~m})$ significant differences between treatments were found only for macro and microporosity. Macroporosity values in the plots under no-till
(DNT) treatment were double the amounts recorded in the area prepared with moldboard plow (DPH) and subsoiler followed by harrow (SH) (Table 1). This behavior can be explained by the lack of soil tilling and the fact that the fascicular root system of sugarcane accumulates a lot of roots in this layer, which favors the maintenance of macropores after replanting. After each harvest the oldest cane roots are decomposed by soil microorganisms and are substituted by new ones, what favors an increase of porosity.

Assessing the root system of sugarcane by different methods on Oxisol in Taruma-SP, Vasconcelos et al. (2003) showed that up to $63.5 \%$ of the sugarcane roots were concentrated in the top layers $(0.00-0.20 \mathrm{~m})$. Conducting similar studies, Camilotti et al. (2006) and Azevedo (2008) evaluating tillage systems in sugarcane after the $4^{\text {th }}$ harvest and replanting respectively, observed that the macroporosity was higher for treatments where there was less soil disturbance. They explained that the lack of tilling and the accumulated organic matter may have possibly changed soil porosity. In a study of soil management systems, Paulino et al. (2004) evaluated five different treatments and did not observe differences in macroporosity at the evaluated depths. This was due to the action of implements in deeper layers, because the same did not occur in the area with no tillage.

Regarding microporosity, no differences were found for layers between 0.00 and $0.40 \mathrm{~m}$ in all treatments (Table 1). This was probably due to furrowing during planting in all plots at the same depth. In this case, the soil movement in the rows during planting reduced the values of this parameter. The same was not observed in the 0.40-0.60 m layer because the microporosity values, except for the area under DNT, were always higher when compared to other treatments, which remained constant. This is probably due to the action of fasciculate roots of sugarcane which helped soil restructuring at this depth.

The values for total porosity (TP) were constant in all treatments and in all layers. This is due to the natural arrangement of soil particles after the accumulation of organic matter on soil surface via crop residues and in soil via the root system of sugarcane, favoring soil aggregation and consequently higher total porosity across its profile, as highlighted by Torres et al. (2015).

\section{Distribution of the root system in soil profile}

\section{Root length density}

Analyzing the development of the roots, we observed that there were differences $(\mathrm{p} \leq 0.05)$ between the different tillage systems and evaluated layers (Table 2).

Regarding root length density (RLD), DPH treatment showed higher value when compared to other treatments. This behavior can be explained by the proceedings implemented in this treatment as: desiccation of the remaining vegetation, lime distribution on the soil surface, lime incorporation with moldboard plow and leveling with light harrow. These actions provided a better environment for the development of roots due to $\mathrm{pH}$ correction of the soil, favoring aeration and improved water distribution in soil profile. In a similar study evaluating root length density and distribution of sugarcane roots by counting the roots from the intersection with the profile wall in three tillage systems, Azevedo et al. (2011) observed that the greatest root length density in the soil occurred in the area where the soil preparation was done with plowing + harrowing, in the layer between 0.00 and $0.20 \mathrm{~m}$ with the greatest concentration of 
roots in the row. However they observed few differences between the treatments in the inter-rows of sugarcane. BattieLaclau and Laclau (2009) evaluating RLD in plant cane areas also observed a higher concentration of roots at depth up to $0.20 \mathrm{~m}$, with the same soil preparation.

\section{Mean distance between roots}

Regarding the mean distance between roots (MDR), the highest observed values ( $\mathrm{p} \leq 0.05)$ were found in treatments with no-tillage (DNT) and stubble thrasher (StHPH), but they were close to those in other treatments, no statistical differences $(p \leq 0,05)$ among them. This proximity can be explained by the use of the furrower and cover of setts with a layer of soil, causing a homogenization of the mean distance between roots in all treatments.

Studies with root present great variability of results, this is probably the reason it was not detected difference. Azevedo (2008) and Azevedo et al. (2011), evaluating soil tillage in sugarcane root study also detected no difference between different types of preparation. While Mello Ivo and Mielnickzuc (1999), working with the corn crop in three different soil preparation, identified a higher density of roots in the $0.0-0.05 \mathrm{~m}$ in no-tillage system, while in the conventional tillage system that occurred in layer below 0.10 $-0.15 \mathrm{~m}$.

\section{Soil exploitation rate and root distribution ratio}

Soil exploitation rate (ER) values did not show significant differences $(p \leq 0.05)$ between treatments, which allows to emphasize that the root system of the plant was not limited by variations between treatments and was able to develop satisfactorily.

With respect to the evaluated depths, the highest values of root length density (RLD), mean distance between roots (MDR), soil exploitation rate (ER) and root distribution ratio (RDR) were observed at the depths of $0.00-0.20$ and 0.60 $0.80 \mathrm{~m}$ (Table 2). This behavior can be explained by better development of fasciculate roots up to $0.20 \mathrm{~m}$ deep. This is because the roots maintained their normal development in all treatments despite the soil disturbance caused by the furrower in the row in all treatments, and the action of other implements in the treatments. The $0.60-0.80 \mathrm{~m}$ soil layers were not disturbed by any of the implements used in the treatments, moreover, the effect of compression caused by the movement of heavy machinery tends to be higher in the layers between 0,00 and $0.40 \mathrm{~m}$ and lower in deeper layers, as evidenced by studies on sugarcane and other crops (Sene et al., 1985;. Torres and Scott, 1999; Paulino et al., 2004; Camargo et al., 2010; Cavalieri et al., 2011; Torres et al., 2015). In fact, the soil structure is maintained and the roots of the plants continue their normal development occupying the entire volume of soil after several cycles of cultivation.

Smith et al. (2005), Battie-Laclau and Laclau (2009) and Azevedo et al. (2011) evaluated the root length density (RLD) and root intersection density (RID), and found that the highest values for these parameters occurred at depths from 0.00 to 0.20 and 0.40 to $1.00 \mathrm{~m}$. They emphasized that the root distribution is a good biological indicator of the physical state of a soil, since lower RLD and RID values were recorded at a depth of $0.20-0.40 \mathrm{~m}$, where there was greater mechanical resistance to root penetration.

Some studies have been conducted to evaluate the quantity of sugarcane roots in the same class of soil using different methodologies with high variability of results. Using five methods to quantify sugarcane roots, Vasconcelos et al. (2003) identified differences in the number of roots between depths for all evaluated methodologies. In general, in all methods the highest concentration of roots was found up to $0.20 \mathrm{~m}$ deep. However, those authors found lower amounts of roots in $0.40-0.60$ and $0.60-0.80 \mathrm{~m}$ layers comparing to what we found in this study. Farias et al. (2008) identified a much higher RLD in the upper layers at the end of the first crop cycle of sugarcane. They observed that the first $0.60 \mathrm{~m}$ concentrated $80 \%$ of the mass of the roots on dryland and $90 \%$ on irrigated area.

Evaluating the RLD (0.00-0.60 m depth) in the state of Paraná, Azevedo et al. (2011) did not identify differences in these parameters at different depths. After the third and fifth harvest of ratoon cane, Costa et al. (2007) identified a decrease in the amount of roots from the surface layer to the deepest layer. The difference between the amount of roots in different layers, increasing with depths, in their work may be due to the use of the methodology proposed by Chopart et al. (2008), which considers the verticality of the growth of sugarcane roots in subsurface layers, a fact that is not observed by other analytical methodologies with wall profile, using SIARCS program to interpret pictures of the exposed roots.

\section{The agronomic characteristics}

\section{Height, diameter, number of steams and productivity of sugarcane}

Regarding the agronomic characteristics of height, diameter, number of steams and productivity of sugarcane, no differences were found between treatments (Table 3). This indicates that soil preparation or its absence did not affect the development of cane plants. Despite testing different types of tillage systems, furrowing at planting allowed sprouting and tillering of sugarcane in similar conditions of initial growth in all treatments. Similar results were found by Paulino et al. (2004), Camilotti et al. (2006) and Azevedo (2008), in studies evaluating different soil tillage systems in sugarcane. They also did not find differences among most agronomic traits of sugarcane. Higher yields occurred in the treatments with desiccation + moldboard plow + light harrow $(\mathrm{DPH})$ and stubble thrasher + mid harrow + moldboard plow + light harrow (StHPH), which showed a difference of about $12 \mathrm{tha}$ 1 when compared to treatments with stubble thrasher + subsoiler (StS) and desiccation + subsoiler (DS) (Table 3). In those areas (DPH and StHPH) soil disturbance was more intense, there was better incorporation of the remaining vegetation and good incorporation of lime and gypsum into the soil profile, which increased aeration and water infiltration of the soil and, consequently, caused better root development and better uptake of nutrients and water, positively affecting crop productivity.

In the area with DNT productivity did not differ significantly from other treatments. It suggests the feasibility of using no-tillage during replanting of sugarcane due to fewer operations in the area, which will certainly decrease the production costs and increase the profitability of the operation. Assessing the yield under five tillage systems, after replanting and expansion of sugarcane plantation, Grange et al. (2004) found the highest yield of plant cane with conventional treatment. It was twice the productivity of the no-tillage system. In the areas where subsoiler was used, productivity was intermediate, which is contrary to the result in this study. 
Table 1. Penetration resistance (PR), soil density (SD), gravimetric moisture (GM), macroporosity (Ma), microporosity (Mi) and total porosity (TP) after replanting of sugarcane with different soil tillage systems in the Cerrado.

\begin{tabular}{|c|c|c|c|c|c|c|}
\hline \multirow[t]{2}{*}{ Treatment } & PR & SD & GM & $\mathrm{Ma}$ & $\mathrm{Mi}$ & TP \\
\hline & Mpa & $\mathrm{Mg} \mathrm{m}^{-3}$ & $\%$ & $\mathrm{~m}^{3} \mathrm{~m}^{-3}$ & & \\
\hline & \multicolumn{6}{|c|}{$0.00-0.20 \mathrm{~m}$} \\
\hline DPH & $2.85 \mathrm{~b}^{\mathrm{ns}}$ & $1.33 \mathrm{a}^{\mathrm{ns}}$ & $18.42 \mathrm{a}^{\mathrm{ns}}$ & $0.09 \mathrm{Aba}^{*}$ & $0.36 \mathrm{Aab}^{*}$ & $0.46 \mathrm{a}$ \\
\hline SH & $3.60 \mathrm{~b}$ & $1.35 \mathrm{a}$ & $17.12 \mathrm{a}$ & $0.08 \mathrm{Ab}$ & 0.34 Aab & $0.43 \mathrm{a}$ \\
\hline DNT & $3.32 \mathrm{~b}$ & $1.29 \mathrm{a}$ & $19.91 \mathrm{a}$ & $0.16 \mathrm{Ca}$ & $0.34 \mathrm{Aa}$ & $0.50 \mathrm{a}$ \\
\hline $\mathrm{BD}$ & $3.67 \mathrm{~b}$ & $1.27 \mathrm{a}$ & $18.42 \mathrm{a}$ & $0.14 \mathrm{BCa}$ & $0.35 \mathrm{Aa}$ & $0.48 \mathrm{a}$ \\
\hline $\mathrm{StS}$ & $2.40 \mathrm{~b}$ & $1.32 \mathrm{a}$ & $20.35 \mathrm{a}$ & $0.10 \mathrm{ABa}$ & $0.38 \mathrm{Aa}$ & $0.48 \mathrm{a}$ \\
\hline \multirow[t]{2}{*}{ StHPH } & $3.02 \mathrm{~b}$ & $1.34 \mathrm{a}$ & $17.47 \mathrm{a}$ & $0.13 \mathrm{ABCa}$ & $0.33 \mathrm{Aa}$ & $0.46 \mathrm{a}$ \\
\hline & \multicolumn{6}{|c|}{$0.20-0.40 \mathrm{~m}$} \\
\hline DPH & $7.65 \mathrm{a}$ & $1.38 \mathrm{a}$ & $19.31 \mathrm{a}$ & $0.10 \mathrm{Aa}$ & $0.35 \mathrm{Ab}$ & $0.46 \mathrm{a}$ \\
\hline $\mathrm{SH}$ & $7.80 \mathrm{a}$ & $1.33 \mathrm{a}$ & $18.05 \mathrm{a}$ & $013 \mathrm{Aa}$ & $0.33 \mathrm{Ab}$ & $0.47 \mathrm{a}$ \\
\hline DNT & $7.25 \mathrm{a}$ & $1.40 \mathrm{a}$ & $20.21 \mathrm{a}$ & $0.10 \mathrm{Ab}$ & $0.32 \mathrm{Aa}$ & $0.43 \mathrm{a}$ \\
\hline $\mathrm{BD}$ & $7.02 \mathrm{a}$ & $1.30 \mathrm{a}$ & $19.35 \mathrm{a}$ & $0.14 \mathrm{Aa}$ & $0.34 \mathrm{Aa}$ & $0.44 \mathrm{a}$ \\
\hline StS & $6.12 \mathrm{a}$ & $1.36 \mathrm{a}$ & $20.41 \mathrm{a}$ & $0.11 \mathrm{Aa}$ & $0.32 \mathrm{Ab}$ & $0.44 \mathrm{a}$ \\
\hline \multirow[t]{2}{*}{ StHPH } & $6.90 \mathrm{a}$ & $1.31 \mathrm{a}$ & $18.95 \mathrm{a}$ & $0.11 \mathrm{Aa}$ & $0.35 \mathrm{Aab}$ & $0.47 \mathrm{a}$ \\
\hline & \multicolumn{6}{|c|}{$0.40-0.60 \mathrm{~m}$} \\
\hline DPH & $6.80 \mathrm{a}$ & $1.28 \mathrm{a}$ & $20.38 \mathrm{a}$ & $0.08 \mathrm{Aa}$ & $0.40 \mathrm{Ba}$ & $0.49 \mathrm{a}$ \\
\hline $\mathrm{SH}$ & $6.27 \mathrm{a}$ & $1.23 \mathrm{a}$ & $18.81 \mathrm{a}$ & $0.11 \mathrm{ABab}$ & $0.38 \mathrm{Ba}$ & $0.50 \mathrm{a}$ \\
\hline DNT & $6.55 \mathrm{a}$ & $1.24 \mathrm{a}$ & $20.18 \mathrm{a}$ & $0.14 \mathrm{Bab}$ & $0.32 \mathrm{Aa}$ & $0.47 \mathrm{a}$ \\
\hline DS & $6.05 \mathrm{a}$ & $1.17 \mathrm{a}$ & $21.42 \mathrm{a}$ & $0.12 \mathrm{ABa}$ & $0.38 \mathrm{Ba}$ & $0.47 \mathrm{a}$ \\
\hline StS & $5.10 \mathrm{a}$ & $1.27 \mathrm{a}$ & $19.48 \mathrm{a}$ & $0.11 \mathrm{ABa}$ & $0.35 \mathrm{Bab}$ & $0.47 \mathrm{a}$ \\
\hline StHPH & $6.70 \mathrm{a}$ & $1.26 \mathrm{a}$ & $18.52 \mathrm{a}$ & $0.10 \mathrm{ABa}$ & $0.38 \mathrm{Ba}$ & $0.48 \mathrm{a}$ \\
\hline $\mathrm{CV}(\%)$ & 20.61 & 8.29 & 20.61 & 22.49 & 7.20 & 7.33 \\
\hline
\end{tabular}

Table 2. Root length density (RLD), mean distance between roots (MDR), soil exploitation rate (ER) and root distribution rate (RDR) after harvest and replanting of sugarcane with different soil tillage systems, in Goianésia GO, in 2010.

\begin{tabular}{|c|c|c|c|c|}
\hline Systems & RLD & MDR & ER & RDR \\
\hline $\mathrm{m}$ & $\mathrm{cm}^{3} \mathrm{~cm}^{-3}$ & $\mathrm{~cm}$ & & \\
\hline \multicolumn{5}{|c|}{ Tillage systems } \\
\hline DPH & $0.329 \mathrm{a}^{*}$ & $2.28 \mathrm{a}^{\mathrm{ns}}$ & $31.04 \mathrm{a}^{\mathrm{ns}}$ & -- \\
\hline SH & $0.297 \mathrm{~b}$ & $2.35 \mathrm{a}$ & $28.83 \mathrm{a}$ & -- \\
\hline DNT & $0.276 \mathrm{~b}$ & $2.56 \mathrm{a}$ & $26.40 \mathrm{a}$ & -- \\
\hline DS & $0.297 \mathrm{~b}$ & $2.48 \mathrm{a}$ & $28.09 \mathrm{a}$ & -- \\
\hline StS & $0.265 \mathrm{~b}$ & $2.52 \mathrm{a}$ & $26.14 \mathrm{a}$ & -- \\
\hline StHPH & $0.294 \mathrm{~b}$ & $2.41 \mathrm{a}$ & $28.38 \mathrm{a}$ & -- \\
\hline DMS & 0.099 & 0.29 & 7.29 & -- \\
\hline $\mathrm{CV} \%$ & 32.82 & 15.48 & 24.98 & -- \\
\hline \multicolumn{5}{|c|}{ Depths } \\
\hline $0.00-0.20$ & $0.324 \mathrm{a}^{*}$ & $2.33 \mathrm{a}^{*}$ & $29.89 a^{*}$ & 27.6 \\
\hline $0.20-0.40$ & $0.253 \mathrm{~b}$ & $2.68 \mathrm{~b}$ & $24.54 \mathrm{~b}$ & 21.6 \\
\hline $0.40-0.60$ & $0.279 \mathrm{ab}$ & $2.48 \mathrm{ab}$ & $27.35 \mathrm{ab}$ & 23.8 \\
\hline $0.60-0.80$ & $0.316 \mathrm{ab}$ & $2.25 \mathrm{a}$ & $30.82 \mathrm{a}$ & 27.0 \\
\hline DMS & 0.07 & 0.28 & 5.34 & -- \\
\hline $\mathrm{CV} \%$ & 32.82 & 15.48 & 24.98 & -- \\
\hline
\end{tabular}

Table 3. Diameter (D), height $(\mathrm{H})$ and the quantity of steams (QS) and productivity (Prod) of sugarcane under different tillage systems in Goianésia GO in 2010.

\begin{tabular}{lcccc}
\hline Treatment & $\mathrm{D}$ & $\mathrm{H}$ & $\mathrm{QS}$ & Prod \\
\cline { 2 - 5 } & $\mathrm{cm}$ & $\mathrm{m}$ & $\mathrm{M}$ & $\mathrm{tha}^{-1}$ \\
\hline DPH & $2.68 \mathrm{a}^{\mathrm{ns}}$ & $2.54 \mathrm{a}^{\text {ns }}$ & $14.87 \mathrm{a}^{\text {ns }}$ & $104.87 \mathrm{a}^{*}$ \\
SH & $2.58 \mathrm{a}$ & $2.37 \mathrm{a}$ & $14.34 \mathrm{a}$ & $95.70 \mathrm{ab}$ \\
DNT & $2.61 \mathrm{a}$ & $2.43 \mathrm{a}$ & $15.37 \mathrm{a}$ & $100.00 \mathrm{ab}$ \\
DS & $2.62 \mathrm{a}$ & $2.52 \mathrm{a}$ & $14.25 \mathrm{a}$ & $93.67 \mathrm{~b}$ \\
StS & $2.67 \mathrm{a}$ & $2.32 \mathrm{a}$ & $15.17 \mathrm{a}$ & $93.52 \mathrm{~b}$ \\
StHPH & $2.67 \mathrm{a}$ & $2.42 \mathrm{a}$ & $14.95 \mathrm{a}$ & $105.34 \mathrm{a}$ \\
CV\% & 6.92 & 10.61 & 4.06 & 4.80 \\
\hline ns $=$ Not sificany
\end{tabular}

${ }^{\mathrm{ns}}=$ Not significant; * Significant $(\mathrm{p} \leq 0.05)$. CV $=$ Coefficient of variation. Means followed by the same lowercase letters in the column compare treatments, which do not differ by Tukey test $(\mathrm{p} \leq 0.05) . \mathrm{DPH}=$ desiccation + moldboard plowing + light harrow; $\mathrm{SH}=$ subsoiler + light harrow; $\mathrm{DNT}=$ Desiccation + no-tillage; $\mathrm{DS}=\mathrm{desiccation}+$ subsoiler; $\mathrm{StS}=$ stubble thrasher + subsoiler; $\mathrm{StHPH}=$ stubble thrasher + mid harrow + moldboard plow + light harrow 


\section{Materials and Methods}

\section{Description of the experimental area}

This study was carried out on a sugarcane plantation replanted after seven successive harvests located in the municipality of Goianésia GO, $\left(15^{\circ} 10^{\prime} \mathrm{S}\right.$ and $\left.49^{\circ} 15^{\prime} \mathrm{W}\right)$ with an average altitude of $640 \mathrm{~m}$ and typical cerrado vegetation. It used the CTC variety -2 , less demanding on fertility.

The soil is classified as Dystrophic Red-Yellow Latosol (Embrapa, 2013), of sandy clay texture in the surface layer (0.00-0.20 m) with the following characteristics: $480 \mathrm{~g} \mathrm{~kg}^{-1}$ of clay, $159 \mathrm{~g} \mathrm{~kg}^{-1}$ of silt, $328 \mathrm{~g} \mathrm{~kg}^{-1}$ of sand, $\mathrm{pH} \mathrm{C}_{\mathrm{a}} \mathrm{Cl}_{2}=4,01 ; \mathrm{P}$ $=1,4 \mathrm{mg} \mathrm{dm}^{-3} ; \mathrm{K}=78,0 \mathrm{mg} \mathrm{dm} ; \mathrm{Ca}=0,45 \mathrm{cmol}_{\mathrm{c}} \mathrm{dm}^{-3} ; \mathrm{Mg}$ $=0,29 \mathrm{cmol}_{\mathrm{c}} \mathrm{dm}^{-3} ; \mathrm{Al}=1,65 \mathrm{cmol}_{\mathrm{c}} \mathrm{dm}^{-3} ;$ organic $\mathrm{C}=16,2 \mathrm{~g}$ $\mathrm{kg}^{-1}$; CEC at $\mathrm{pH} 7,0=9,19 \mathrm{cmol}_{\mathrm{c}} \mathrm{cm}^{-3}$ and $10,2 \%$ base saturation. The deeper layer $(0.20-0.40 \mathrm{~m})$ showed the following characteristics: $533 \mathrm{~g} \mathrm{~kg}^{-1}$ of clay, $139 \mathrm{~g} \mathrm{~kg}^{-1}$ of silt e $361 \mathrm{~g} \mathrm{~kg}^{-1}$ of sand, $\mathrm{pH} \mathrm{C}_{\mathrm{a}} \mathrm{Cl}_{2}=3,97 ; \mathrm{P}=0,7 \mathrm{mg} \mathrm{dm}^{-3} ; \mathrm{K}=$ $19,2 \mathrm{mg} \mathrm{dm}^{-3} ; \mathrm{Ca}=0,23 \mathrm{cmol}_{\mathrm{c}} \mathrm{dm}^{-3} ; \mathrm{Mg}=0,15 \mathrm{cmol}_{\mathrm{c}} \mathrm{dm}^{-3}$; $\mathrm{Al}=2,0 \mathrm{cmol}_{\mathrm{c}} \mathrm{dm}^{-3}$; organic $\mathrm{C}=10,4 \mathrm{~g} \mathrm{~kg}^{-1}$; $\mathrm{CEC}$ at $\mathrm{pH} 7,0$ $=9,12 \mathrm{cmol}_{\mathrm{c}} \mathrm{cm}^{-3}$ and $4,8 \%$ base saturation. The climate of the region is Aw (megathermal) or tropical savannah, hot and humid, with rainy summers, according to Köppen. During the experiment the temperature varied from $21.8^{\circ} \mathrm{C}$ (minimum) in June to $26.1^{\circ} \mathrm{C}$ (maximum) in September 2009, with total rainfall for the period of $1435 \mathrm{~mm}$. From January to May 2010 the accumulated rainfall was $570 \mathrm{~mm}$.

\section{Soil management and cultivation}

The correction of soil acidity was carried out following recommendation for the entire experimental area by applying dolomitic limestone (TNP 85\%) in a single dose $\left(1.5 \mathrm{t} \mathrm{ha}^{-1}\right)$ on the surface of the soil. This amendment was later mixed with the soil during the different soil preparation treatments, except for the area with no-till system where there was no incorporation. Before the planting six treatments were established. They were the combinations of different tilling actions whose aim was to mix limestone with soil, eliminate compacted layers and control weeds. Shortly after the implantation of the treatments and before sugarcane planting, topdressing with gypsum $\left(0.8 \mathrm{t} \mathrm{ha}^{-1}\right)$ was performed in the total area, without incorporation. The use of this single dose aimed to eliminate another source of variation. Desiccation of the volunteer plants, particularly Brachiaria, was performed before the experiment by applying glyphosate $+2.4 \mathrm{D}$ in the area at doses of 3.0 and $2.0 \mathrm{~L} \mathrm{~h}^{-1}$.

\section{Experimental design and description of treatments}

To assess the physical soil attributes the experimental design was randomized blocks, in $6 \times 3$ factorial scheme with 6 soil treatments: $\mathrm{T}_{1}=$ Desiccation + moldboard plowing + light harrow $(\mathrm{DPH}) ; \mathrm{T}_{2}=$ Subsoiler + light harrow $(\mathrm{SH}) ; \mathrm{T}_{3}=$ Desiccation + no-tillage $(\mathrm{DNT}) ; \mathrm{T}_{4}=$ Desiccation + subsoiler (DS); $\mathrm{T}_{5}=$ stubble thrasher + subsoiler $(\mathrm{StS}) ; \mathrm{T}_{6}=$ stubble thrasher + mid harrow + moldboard plow + light harrow (StHPH), evaluated at three depths $(0.0-0.20 ; 0.20-0.40$ and $0.40-0.60 \mathrm{~m})$, with 4 repetitions. In all treatments, planting was done using a sugarcane furrower/ fertilizer applicator.

\section{Root development}

The evaluation of the roots in the profile was carried out using $6 \times 4$ factorial scheme with 6 treatments evaluated at 4 depths $(0.00-0.20 ; 0.20-0.40 ; 0.40-0.60$ and $0.60-0.80 \mathrm{~m})$ with 4 four repetitions. The profile of each evaluation area was composed of 15 squares $(0.10 \times 0.10 \mathrm{~m})$ in horizontal and 8 in vertical. This way the development of the root system was evaluated at $0.0-0.8 \mathrm{~m}$ depth by 1.5 meters long, in the inter-rows of plants in each plot. To evaluate agronomic (diameter, height, number of stems) and productivity (stems per hectare) comparison of traits among plots was performed. Each block comprised six plots, each 50 $\mathrm{m}$ long and $19.5 \mathrm{~m}$ wide, with 13 rows spaced $1.5 \mathrm{~m}$ apart. To separate the blocks and the plots, $5 \mathrm{~m}$ wide technical paths were established to facilitate the operation of machines and implements. Thus, the area of each plot was approximately $1000 \mathrm{~m}^{2}$ and the total area of the experiment 2.4 hectares.

\section{Fertilization at planting and topdressing}

Planting of the CEC -2 of sugarcane variety was done manually in April 2009 placing 15 to 20 setts per meter into furrows made by a sugarcane furrower/fertilizer applicator. This planting system is also called direct planting. The fertilization at planting, for all treatments, was done by placing the fertilizer into the furrows, distributing $250 \mathrm{~kg} \mathrm{ha}^{-1}$ of monoammonium phosphate (MAP), an equivalent to 120 $\mathrm{kg} \mathrm{ha}^{-1}$ of $\mathrm{P}_{2} \mathrm{O}_{5}$ and $28 \mathrm{~kg} \mathrm{ha}^{-1}$ of N. In September of the same year topdressing was performed with a liquid fertilizer formulation $(05-00-13+0,3 \%$ of $\mathrm{Zn}+0,3 \%$ of $\mathrm{B})$ by applying $1000 \mathrm{~L} \mathrm{ha}^{-1}$, an equivalent to $50 \mathrm{~kg} \mathrm{ha}^{-1}$ of $\mathrm{N}, 130 \mathrm{~kg}$ $\mathrm{ha}^{-1}$ of $\mathrm{K}_{2} \mathrm{O}, 3 \mathrm{~kg} \mathrm{ha}^{-1}$ of $\mathrm{Zn}$ and $\mathrm{B}$.

\section{Evaluation of soil physical attributes}

\section{Soil compaction indicators}

The soil mechanical resistance to penetration (PR) was estimated in the inter-rows after the implementation of the treatments using impact penetrometer Model IAA / Planalsucar with conical tip angle of $30^{\circ}$ (Stolf, 1991). Five measurements of PR were carried out in each plot at the depths of $0.00-0.20 ; 0.20-0.40$ and $0.40-0.60 \mathrm{~m}$. Field data were obtained using the numbers of impacts $\left(\mathrm{dm}^{-1}\right)$, further converted into $\mathrm{kgf} \mathrm{cm}^{-2}$ through the equation $\mathrm{R}\left(\mathrm{kgf} \mathrm{cm}^{-2}\right)=$ $5.6+6.98 \mathrm{~N}$ (Sene et al. 1985). Next, these values were multiplied by the 0.098 constant for processing in Mpa units, according to Arshad et al. (1996). Per plot, three soil samples from the inter-rows were taken to determine moisture at the same depths of PR evaluation. Next, they were weighed and taken to dry in an oven at $105^{\circ} \mathrm{C}$ for 24 hours. Later, their oven-dried mass was recorded, and finally soil moisture was determined (Embrapa, 2011). The soil density (SD) was determined by the volumetric ring method with rings $0.05 \mathrm{~m}$ long $\times 0.05 \mathrm{~m}$ diameter using undisturbed soil samples extracted with Uhland auger at depths of $0.00-0.20 ; 0.20-0.40$ and $0.40-0.60 \mathrm{~m}$. The samples were dried at $105^{\circ} \mathrm{C}$ for $24 \mathrm{~h}$ as described by Blake and Hartge (1986). The pore size distribution was estimated using the same soil samples set for BD. First, the samples were saturated for $24 \mathrm{~h}$, and then they were placed in a suction unit at $0.60 \mathrm{~m}$ of water column. The soil macroporosity (Ma), total porosity (TP) and microporosity (Mi) were estimated according to Embrapa (2011).

\section{Sugarcane harvest and productivity}

To estimate the productivity, the dried leaves of the plants were burned at night one day before the harvest to avoid drying of the steams. Next, the steams were cut down 
manually at the ground level and the top parts of the plants were cut off in the region where green leaves still remained. The evaluation of the number of steams/plant was done ten months after planting, counting all stems in 5 central rows each $35 \mathrm{~m}$ long. The plot area was $225 \mathrm{~m}^{2}$. Ten steams per plot located on the central line were selected to evaluate their diameter and height. The diameter of the third internode from the base to the top was measured with a digital caliper, while the height was measured with a tape.

\section{Quantification and root development}

\section{Crossings roots}

To evaluate root system development, the number of intersections of the roots with grid placed on the soil profile was determined. This methodology is known as trench profile wall method and was also used by Azevedo et al. (2011). With the aid of a backhoe, a pit ( $1.5 \mathrm{~m}$ wide and $0.80 \mathrm{~m}$ deep) was dug in each plot, where the grid was positioned. Then, with the aid of a hoe, the wall of the profile was prepared so that it formed a $90^{\circ}$ angle to the trench bottom.

\section{The counting of the number of roots}

In order to expose the roots across the profile a rake was used. Next, the plane of observation was overlaid with a grid ( $1.5 \mathrm{~m}$ wide and $0.80 \mathrm{~m}$ deep) consisting of $0.10 \times 0.10 \mathrm{~m}$ squares in a way that the screen edge coincided with the surface of the inter-row of sugarcane plants. Then, the counting of the number of roots intersecting with (emerging from) the soil (RIC) was performed in each square of $0.10 \mathrm{x}$ $0.10 \mathrm{~m}$. Finally, in the computer lab, the obtained field data were processed by RACINE software 2 (Chopart et al., 2008) responsible for modeling the root length density (RLD), mean distance between roots (MDR) and soil exploitation rate (ER) based on the root intersection count (RIC).

\section{Statistical analysis}

The results were analyzed for normality and homogeneity of data through Lilliefors Cochran and Barttlet tests, respectively. The physical attributes and evaluated indices were submitted to analysis of variance using the SISVAR statistical program, applying the $\mathrm{F}$ test for significance and means compared by Tukey test $(\mathrm{p} \leq 0.05)$.

\section{Conclusions}

The evaluated soil tillage systems eased the problem of resistance to root penetration only at the depth to $0.20 \mathrm{~m}$. The area under no-tillage showed the highest macroporosity values when compared to tillage systems; The best rates for root development occurred in the preparation system with desiccation + moldboard plow + light harrow $(\mathrm{DPH})$; The best development of sugarcane roots occurred at the depths of 0.00 to 0.20 and $0.60-0.80 \mathrm{~m}$; The productivity of sugarcane was significantly higher in systems with greater soil disturbance.

\section{Acknowledgements}

The authors thanks the Federal Institute of Triangle Miner, Campus Uberaba, for the available infrastructure; the Research Supporting Foundation for the State of Minas Gerais (Fapemig); and the National Council for Scientific and
Technological Development (CNPq) for funding the project and granting scholarship.

\section{References}

Arshad MA, Lowery B, Grossman B (1996) Physical tests for monitoring soil quality. In: Doran JW, Jones AJ (Eds.), Methods for assessing soil quality. S Sc Soc Am J. 49:123141.

Azevedo MCB (2008) Efeito de três sistemas de manejo físico do solo no enraizamento e na produção de cana-deaçúcar. 100 f. Tese (Doutorado) - Faculdade de Agronomia, Universidade Estadual de Londrina, Londrina.

Azevedo MCB, Chopart JL, Medina CC (2011) Sugarcane, root length density and distribution from root intersection counting on a trench-profile. Sci Agr. 68: 94-101.

Battie-Laclau P, Laclau JP (2009) Growth of the whole root system for a plant crop of sugarcane under rainfed and irrigated environments in Brazil. Fiel Cr Res. 114: 351360.

Blake GR, Hartge KH (1986) Bulk density. In: Klute A (Ed.) Methods of soil analysis: Physical and mineralogical methods. 2.ed. Madison, Am Soc of Agr So Sci Soc of Am. p.363-375.

Camargo LA, Marques Júnior J, Pereira GT (2010) Spatial variability of physical attributes of alfisol under different hillslope curvatures. R Br Ci Sol. 34: 617-630.

Camilotti F, Andrioli T, Marques MO, Silva AR, Tasso Júnior LC, Nobile FO (2006) Atributos físicos de um latossolo cultivado com cana-de-açúcar após aplicações de lodo de esgoto e vinhaça. Eng Agríc. 26: 738-747.

Campos FS, Alves MC, Souza ZM, Torres JLR (2015) Cropping systems evaluation, fertilization, and effects on technological quality and sugarcane productivity. Afr Jour of Agr Res. 10: 3387-3393.

Cavalieri KMV, Carvalho LA, Silva AP, Libardi PL, Tormena CA (2011) Qualidade física de três solos sob colheita mecanizada de cana-de-açúcar. $\mathrm{R} \mathrm{Br} \mathrm{Ci} \mathrm{Sol.} \mathrm{35:}$ 1541-1549.

Carvalho LA, Rezende, IS, Panachuki E, Silva Junior CA, Novak E, Silva GSC (2014) Variáveis físicas do solo e produtividade de cana-de-açúcar sob sistemas de preparo na reforma de canavial. Ce Ci Conh. 1: 259-274.

Chopart JL, Rodrigues SR, Azevedo MCB, Medina CC (2008) Estimating sugarcane root length density through root mapping and orientation modelling. Plant Soil. 313:101-112.

Conab-Companhia Nacional de Abastecimento (2015). Acompanhamento da safra brasileira: grãos, v.1 safra 2014/2015, n.4, Quarto levantamento, Brasília, 34 p.

Costa MCG, Mazza JÁ, Vitti GC, Jorge LAC (2007) Distribuição radicular, estado nutricional e produção de colmos e de açúcar em soqueiras de dois cultivares de canade-açúcar em solos distintos. R Br Ci Sol. 31: 1503-1514.

Embrapa - Empresa Brasileira de Pesquisa Agropecuária. Centro Nacional de Pesquisa de Solos (2011) Manual de métodos de análise de solos. 2.ed. Rio de Janeiro: EMBRAPA, 230p.

Embrapa - Empresa Brasileira de Pesquisa Agropecuária (2013) Sistema brasileiro de classificação de solos. $3^{a}$ ed. Brasília, DF; 2013, 353p.

Farias CHA, Fernandes PD, Azevedo HM, Neto JD (2008) Índices de crescimento da cana-de-açúcar irrigada e de sequeiro no Estado da Paraíba. R Br Ci Sol. 12: 356-362.

Grange I, Prammanee P, Prasertsak P (2004) Comparative analysis of different tillage systems used in sugarcane (Thailand). Aus Far Bus Man Conf. 2: 43-59. 
Mello Ivo Wmp, Mielniczuk J (1999) Influência da estrutura do solo na distribuição e na morfologia do sistema radicular do milho sob três métodos de preparo. $\mathrm{R} \mathrm{Br} \mathrm{Ci}$ Sol. 23:135143.

Oliveira Filho FX, Miranda NO, Medeiros JF, Silva PCM, Mesquita FO, Costa TKG (2015) Zona de manejo para o preparo do solo na cultura da cana-de-açúcar. R Br Eng Agric Amb. 19:186-193.

Paulino AF, Medina CC, Azevedo MCB, Silveira KRP, Trevisan AA, Murata IM (2004) Escarificação de um Latossolo Vermelho na pós-colheita de soqueira de canade-açúcar. R Br Ci Sol. 28: 911-917.

Pellin DMP, Montanari R, Lima ES, Lovera LH, Corrêa AR (2015) Variabilidade de atributos físicos de um Latossolo Vermelho sob cultivo de cana-de-açúcar. Caat. 28: 28-38.

Sene M, Vepraskas MJ, Naderman GC, Denton HP (1985) Relationsships of soil texture and structure to corn yield response to subsoiling. S Sc Soc Am Jou. 49: 422-427.

Smith DM, Inman-Barber NG, Thorburn PJ (2005) Growth and function of the sugarcane root system. Fi Crop Res. 92: 169-183.

Souza GS, Souza ZM, Silva RB, Barbosa RS, Araújo FS (2014). Effects of traffic control on the soil physical quality and the cultivation of sugarcane. R Br Ci Sol. 38:135-146.

Stolf R (1991) Teoria e teste experimental de fórmulas de transformação dos dados de penetrômetro de impacto em resistência do solo. $\mathrm{R}$ Br Ci Sol. 15: 229-35.

Tavares RLM, Farhate CVV, Souza ZM, Scala Junior M, Torres JLR, Campos MCC (2015) Emission of $\mathrm{CO}_{2}$ and soil microbial activity in sugarcane management systems. Afr Jour of Agric Res. 10: 975-982.
Torres JLR, Pereira MG, Assis RL, Souza ZM (2015) Atributos físicos de um Latossolo Vermelho cultivado com plantas de cobertura, em semeadura direta. $\mathrm{R} \mathrm{Br} \mathrm{Ci} \mathrm{Sol.} \mathrm{39:}$ 428-437.

Torres E, Saraiva OF (1999) Camadas de impedimento do solo em sistemas agrícolas com a soja. Londrina: Embrapa. 58p. (Circular Técnica, 23).

Vasconcelos ACM, Casagrande AA, Perecin D, Jorge LAC, Landell MGA (2003) Avaliação do sistema radicular da cana-de-açúcar por diferentes métodos. $\mathrm{R} \mathrm{Br} \mathrm{Ci}$ Sol. 27:849-858.

Vasconcelos ACM, Casagrande AA (2008) Fisiologia do sistema radicular. In: Dinardo-Miranda LL, Vasconcelos ACM, Landell MGA (Ed.). Cana-de-açúcar. Campinas: Instituto Agronômico, 882p.

Vasconcelos RFB, Cantalice JRB, Oliveira VS, Costa YDJ, Cavalcante DM (2010) Estabilidade de agregados de um latossolo amarelo distrocoeso de tabuleiros costeiro sob diferentes aportes de resíduos orgânicos da cana-de-açúcar. R Br Ci Sol. 34: 309-316. 